\title{
Emotional Violence Caused by the Effect of Parents' Rolein Cultural Hegemony of Social Control on Children in Lia Shine's TerpaksaMenikah: A Case Study
}

\author{
Putra Pratama Saputra \\ Sociology, The Faculty of Social and Political Science \\ University of Bangka Belitung \\ Email: putra-pratama@ubb.ac.id / putraps92@gmail.com
}

\begin{abstract}
Emotional violence is violence that can frustrate social development on children or mental health children. Emotional violence is verbal violencethat is usually received by the involving feelings in himself. This will impact that distasteful to the development of children. According to Moffat "emotional violence will make children unable to give or receive affection normally". Research has a reference to see hegemony cultural influenced by violence emotional, where hegemony culture is an aspect of leadership where it is dominated by a class that cause a pressure in the domain of the habit or culture. This relatively relation to social control in emotional children. So it will be examined through the theory of social control which will show expectation of violent emotional to the development of children.
\end{abstract}

Keywords: Emotional violence, Hegemony Culture, and Social Control

\section{INTRODUCTION}

Violence has been one of the problems of life in the public domain. One violence to another always happens. Violence is a not worthy of being physically loss or danger, psychological, or financially good suffered by individuals or groups. One of these is the emotional violence. According to Wong (1996) emotional child abuse is an act of oral or conduction that gives rise to adverse emotional consequences. Violence in the progress of society has penetrated in social problems. Number of caused violence act impact is not expected to become a trigger to the collapse of social control in society.

For that variety of violence that is happening ranging from physical abuse, emotional, and others, physical abuse is usually carried out the act of one who detrimental to physical others. Violence is usually known from the location of the violence, namely a social environment and family environment. Here researchers will talk about of violence that is happening in a family which is pertaining to emotional violence. In which researcher will try to study emotional violence problems of one of novel titled "Forced to Married" by Lia Shine. The novel is the work of a native son Pusuk Village, Kelapa, West Bangka of Regency.

The researchers will study phenomena of emotional violence from the history told by the author in the novel. The history of novel can be used as one example of violent emotional in which parents do for their children through emotional instruction. Therefore, emotional violence has to do with hegemony culture social control on children. Hegemony according to Gramsci is "In control leadership intellectual and moral received by voluntary through awareness" (Nezar Patria \&AndiArief, 2003). For that hegemony culture is repression leadership based on power in terms of moral and intellectual that a affects the habit or culture.

It is also cannot be apart from social control. Social control is a system by which education has a chance to take, even force the community to behave in accordance with values andnorms in order that the lives of ordinary people for helping 
and protecting in an orderly fashion. According to Joseph R. Roucek (2011) "Social control is the process which is planned or is unplanned to teach individuals to make it adapt to the habit and values a group in which the live". Emotional violence is reflected from a history that was delivered in the novelentitled TerpaksaMenikah will be analyzed by researchers that there may be some relation to the hegemony of culture social control to children.

Emotional violence problems will be drawn through the establishment of the disparities cultural hegemony that has impact on the childrenemotion. The diversity of discipline will have an impact that is not good on the psychology of children. It happens to be described in the history of the novel, which will be explained how violent emotional resulting in social control. Maturity age will be influential on children mentality, manifested of the instructional age before getting of adult. It ia not in contrast to approach verbally used by older people in educating them that exert pressure or influence on children.

Because of that, this research aims to find out how the violent emotional done by parents so as to affect the hegemony of cultural social controls for children and factors anything that affects a violent emotional on children. This research tries to give a sense of an accurate assessment of the form of a strengthening social control in space the sphere of emotional violence. There are two purposesthat are to: Identify a violent onset emotional conducted by parents thataffect cultural hegemony of social control on children and identify the factors that affect emotional violence on children.

In examining this problem, researchers used one of a breed of the theory that is the theory of social control. According to Soerjono Soekanto (2007) "Social control (social control) is the good processthe planned or not premeditated, which aims to say to us, guide, or force the community to abide by norms and values prevailing". For that understanding the theory control (control theory) to refer to any perpective that is one of the things that discusses control human behavior. Meanwhile, social control understanding (social control) refers to delinkuensi discussion and the hardness that is associated with such variables which is a sociologycal perspective, among others family structure, education, and clusters of dominant.

The emergence of the theory social control is caused by three variety of development, viz: (1) The reaction to orientation labelling and conflicts; (2) The appearance of the study of criminal justice; and (3) The theory of social control has been associated with a new technique research especially for son/teenager behavior. In 1951, Albert J. Reiss, Jr. was bringing the concept of personality and this socialization with the research the flow of chicago, and has produced the theory social control. Reiss request suggested that there are three components of social control in clarifying of problems that emerged on children, viz: (1) A lack of an internal control reasonable during the children; (2) Loss of socialcontrol; and the (3) the absence of social norms of conflict between norms referred to (at the school, parents and environment near).

For it, researchers used this theory aims to asses a phenomenon in the family, the family especially parents have a role as the media child development. According to Horton and Hunt (1991) "Families are groups the primary the first of a child and from that the development of personality". This theory will be used to analyse cultural hegemony formed or occurred in children when a social control formed imperfect affection to the cultural hegemony formed byemotional violence. Therefore this theory will be no relation to Reiss request about three components of social control in explain the matter in children. Moreover, it is also explained about the personal control about the ability of someone to hold the feeling not to reach their own need by breaking the social norms happened as a result of emotional violence

\section{METHOD}

This research in a qualitative research. Sugiyono (2014) says that "The qualitative 
research is the method used for research on condition natural objects". Qualitative research aims to obtain understanding of meaning, find relationship pattern which is interactive even describingcomplex reality. Therefore, this research usesdialectical method data analysis, namely the data from a book or novel comparing between the phenomena happened in a manuscript novel with studies social done.

\section{DISCUSSION}

\section{A. The Role of Parents in Playing Emotional Violence that Affects Cultural Hegemony on Social Control}

Among the community has not already been something that is considered foreign. Violence is classified into two parts of physical violence and non physical. The research will be discussed about non physical violence, namelyemotional violence. Emotional violenceis violence that makes children who are unable to give or receive affection in a normal way. Emotional violencebased on inner pressure a child, that is usually influenced by its environment own. One of them is from the role of the instruction of parents. Emotional violence problem is not regarded as a simple matter in which is not less important to the issue of physical abuse. Emotional violenceit will be difficult for examining because it relates to the condition of the feeling of one.

Further emotional violenceis also closely related to verbal violence. This violence is a deliberateact of resulting in physical and mental stress quarrels and dissension. Cambell and Humphrey define "Children violence is the cause of great trouble or any action against health and the welfare of children carried out by someone who should become responsible for the health and welfare of children is". Hence, this is what was the reason for the researchers study in very simple terms about violent emotional with an analysis of the problems with figures of novels "TerpaksaMenikah".

The novel tells us that their two young people who used to be forced to be married because there was a history and agreement both their parents. It is going to be a little flashback to the Siti Nurbaya in which her day of marriage carried out through an arranged marriage. This will illustrate that emotional violencereceived by his son with the allegation of pressure and constraints experienced by children, so that it will have an impact on emotional the son of though it can be said to not appear to be, but can be drawn through emotional in himself.

Analysis Manuscript Novel "Forced to Married" Pertaining to Violent Emotional on Child:

Emotional violence plays through violence verbal by parents. In which a child forced something beyond interest and desires that will bring sustainable impacts on child. For that, researchers try to link a manuscript of this novel to the hegemony of culture of social control on childrenthat will be influenced by violent emotional. It is also seen in a manuscript of novels, namely:

"Whatever you like to be in noisy to night or till dawn all. What is important next week you must marry. Mami stared at them by turns".(Page 20)

This shows one verbal violence by parents to his son, because of the requirement that should be a child. But it is not based on the wish of her feelings and will. Violence as it is not pointed directly physically, but can be a trigger to non physical violence. Some experts say that non physical violence is dangerous and has a sustainable relativity. Non physical violence is intended to violence that is intangible. It means, it could not be immediately known his behavior when there is less on that. Because there is no physical touch of investors and the parents and children.

Emotional violent behavior will affect cultural hegemony on children, which is the way that the leads to the family who give sustainable impacts as a result of emotional violencethey received when getting education from their parents. Hegemony culture is an aspect of leadership in which it is dominated by a class causing a pressure to the habit or culture. This would cause an emotional fundamental that can be felt or influential 
on the children psychology. It is also described in the novel, namely:

"If you do not want to marry Lady be my guest. But let just say our relationship ended, you can go anywhere and married with anyone. Consider Mami exposed to damn because has given birth to a son disobeyed like you, go and do not Mami until the end of time".(Page21)

This indicates a demand or utterance of parents who signify an element coercion. It is seen when parents issue words that is not proper to be delivered. Parents' language or speech will affect the emotion of children. Therefore, emotional violenceor verbal violence will be sustainable. For that this should be associated with hegemony cultural and social control on children, because with the social control that has played a role can arrange and form the character of a child. The goal is to deep emotional especially social regularity.

For that behavior according to Notoatmodjo (2003) is "The process of forming the behavioral changes a person affected by factors that come from within and from outside". A faktor in includes knowledge, intelligence, emotion and motivation, while other external factors that is the family, culture, and the environment. Hence, should the role of parents in educating not only to educate, but the aspect of verbal or language which is used must be considered well. Language that are to be delivered moreover used to filter it out so that they do not resulted in a fall in child emotional states.

When a child get a pressure, it will be the opening set along with a sense of dismay inner deeply on a child. A simple thing will act by the difference a feeling of being accepted. If it is continuing, it will give the effect of prolonged even it can make the impact strong. The contents of a manuscript of novels for example the disappointment of children resulting from pressure the verbal delivered their parents, namely:

"Alvend until surprised hear it. 'Mi...... I.......' He was even unable to go ahead with his speech. His heart really saying. Alvend do not believe, Mami can said he was the son of rebellious. And what was so sad is Mami said exposed to damn because has borne him". (Page 21)

"Is not different from Alvend, Lady also is too frustrated with this marriage plan". (Page 22)

Some subjects of above shows simply that an element violence that is received by the emotional. It is described by means of pressure shown by their parents. Hence, need the role of social control in realizing hegemony culture or a good habit on child. As a result, at the time hegemony culture social control create a good, so the degree of hardness emotional on child relatively low.

\section{B. Factors Influencing The Emotional Violence On Child}

There are several factors the cause of violent emotional on child, among:

1. The character of parents by using verbal that is too harsh

It is usually indicated parents of verbal done contains elements violence. So as to cause the violent emotional that they will receive by the son. Therefore, it impacts on the character of a child.

\section{Parents who are protective}

Parents who are protective and limits freedom to children will have an influence of crimes against emotional children. Hence, this resulted in the deep distress, especially the inner and outward children.

3. Physical abuse done by parents

Physical abuse is usually the parents for their child with hurt or in other words do violence against physical children. It is also, resulting in violent emotional. In which the impact the to seem or naked eyes, that can only be perceived a child are pressure or trauma.

4. Children as place of the parents are wreak anger

Itusually happens when parents who have trouble outside his family. When at home, a parent can hardly control emotionally, therefore the son who are victims or emotional target.

5. The attitude of a pretty bad boy

Usually this is the one of the factors driving force behind many children experienced emotional violence. The course of childhood that tends to active or 
wanton attitude can fishing parents who were protective, hard, and rein.

\section{CONCLUSION}

Violent emotional is violence who makes children is unable to give or receive affection should normally. It is based on inner pressure a child. Usually affected by the environment, especially form the role of discipline done parents. It is also, violent emotional connected with violence verbal received children. His conduct the deliberate can cause injured physical or mental stress. Cambell and Humphrey define "Violence children as any action evil/can harm health and welfare children done by someone who should responsible for health and welfare these children". For it, researchers will be looking at simply of violent emotional with an analysis of the problems happened to the novel "Forced to Marry".

As for factors that have brought about violent emotional on child among: (1) The character of parents/verbal used tending to hard; (2) Parents who were protective; (3) Physical abuse done parents; (4) As place of the parents vent anger; as well as (5) The attitude of a pretty bad boy. Because of that, the results from the analysis of novel "Forced to Married" this show the reality that violence the characters emotional parents affecting the hegemony of culture social control on child.

\section{BIBLIOGRAPHY}

Atmasasmita, R. (2005). TeoridanKapitaSelektaKriminologi (EdisiRevisi).Bandung: RefikaAditama.

Horton, P. B. \& Chester L. H. (1991). Sosiologi, Edisi 6 Jilid I. (DiterjemahanOlehAminudin Ram \&TitaSobari). Jakarta: Gramedia.

Munawati.

(2011).

Hubungan

Verbal

Abuse

denganPerkembanganKognitifpadaAnakUsiaPrasekolah di RW 04 KelurahanRangkapan Jaya BaruDepok. Jakarta: Skripsi S-1 FakultasllmuilmuKesehatan Program StudillmuKeperawatan: Universitas Pembangunan Nasional "Veteran" Jakarta.

Nezar P. \& Andi A. (2003). Antonio Gramsci Negara danHegemoni. Yogyakarta: PustakaPelajar.

Roucek, S. J. \& Warren, L. R. (1984).PengantarSosiologi (DiterjemahkanOlehSahatSimamora). Jakarta: BinaAksara.

Shine, L. (2017). Novel TerpaksaMenikah.Kendal Jawa Tengah: Hanami.

Soerjono S. (2007). PengendalianSosialdalamMasyarakat. Jakarta: Rajawali Pers.

Sugiyono.(2014). MemahamiPenelitianKualitatif.Bandung: Alfabeta.

Wong, D. L. (1996).Wong \& Whaley's Clinical Manual of Pediatric Nursing, Fourth Edition. St. Louis Missouri: Mosby. 